\title{
CAR-T-ICI: KOMBINASI CHIMERIC ANTIGEN RECEPTOR T-CELL DENGAN IMMUNE CHECKPOINT INHIBITOR ANTI $P D-1$ SELAKU PILIHAN TERAPI TERBARU KANKER KOLOREKTAL
}

\author{
Eddy Zulfikar ${ }^{1}$, Imam Hermansyah ${ }^{1}$ \\ ${ }^{1}$ Program Studi Profesi Dokter, Fakultas Kedokteran, Universitas Hasanuddin, Makassar
}

\begin{abstract}
Korespondensi:
Imam Hermansyah

Email author:

imamher5@gmail.com

Riwayat Artikel

Diterima: 20 Maret 2021

Selesai revisi: 6 Juli 2021

DOI :

10.53366/jimki.v9i1.339
\end{abstract}

\section{ABSTRAK}

Pendahuluan: Kanker kolorektal selaku keganasan ketiga tersering di dunia umumnya ditangani dengan operasi, radioterapi, maupun kemoterapi berdasarkan stadium penyakitnya. Namun, akibat prosedur invasif dan efek samping yang ditimbulkan oleh terapi tersebut, Chimeric Antigen Receptor (CAR) T-cell hadir sebagai pilihan terapi terbaru yang bersifat lebih spesifik terhadap sel tumor. Efektivitas CAR T-cell untuk mengobati tumor padat masih terbatas oleh karena molekul imun inhibitorik, Programmed Cell Death-1 (PD-1) yang memiliki efek imunosupresif terhadap sel $\mathrm{T}$. Oleh karena itu, penyusunan literature review ini bertujuan untuk mengkaji potensi terapi kombinasi imunoterapi $C A R-T$ cell dengan anti $P D-1$ dalam pengobatan kanker kolorektal stadium lanjut.

Metode: Literature review ini disusun menggunakan metode studi pustaka hingga diperoleh sebanyak 31 jurnal yang memenuhi kriteria.

Hasil dan Pembahasan: Berdasarkan studi sebelumnya, ekspresi EpCAM dalam jumlah tinggi ditemukan pada sel kanker kolorektal. Sekresi IFN- $y$ dan $T N F-\alpha$ dalam jumlah yang tinggi ditemukan pada sel tumor EpCAM positif menunjukkan bahwa EpCAM-CAR-T cell memiliki efek sitotoksik spesifik terhadap sel tumor target. Rata-rata volume tumor kolorektal pada kelompok EpCAM CAR-T cell lebih rendah dibanding kontrol, menunjukkan EpCAM-CAR- $T$ cell mampu menghambat pembentukan dan pertumbuhan sel tumor. Di sisi lain, 35,8\% pasien kanker kolorektal metastasis diketahui memiliki objective response rate dan $73,6 \%$ diantaranya tercatat memiliki disease control rate $\geq 12$ minggu setelah terapi anti PD-1 nivolumab, menunjukkan efektivitas nivolumab dalam pengendalian penyakit jangka panjang dengan masa survival yang lebih lama pada pasien kanker kolorektal metastasis.

Simpulan: Kombinasi imunoterapi EpCAM CAR-T cell dengan anti PD-1 memiliki potensi sebagai pengobatan terbaru yang efektif untuk kanker kolorektal stadium lanjut.

Kata kunci: Anti PD-1, CAR-T cell, imunoterapi, kanker kolorektal 


\title{
CAR-T-ICI: COMBINATION OF CHIMERIC ANTIGEN RECEPTOR T-CELL WITH ANTI PD-1 IMMUNE CHECKPOINT INHIBITOR AS A NOVEL TREATMENT FOR COLORECTAL CANCER
}

\begin{abstract}
Background: Colorectal cancer (CRC) as the third most common malignancy in the world is generally treated by surgery, radiotherapy, or chemotherapy based on the stage of the cancer. However, due to the invasive procedures and adverse reactions, scientists are developing treatment advancements with immunotherapy, especially Chimeric Antigen Receptor (CAR) T-cell which is considered more specific to tumor cells. However, the effectiveness of CART-T cells to treat solid tumors is still limited by Programmed Cell Death-1 (PD-1) through its immunosuppressive effect on $T$ cells, hence the addition of anti PD-1 to CAR-T cells treatment is deemed necessary to increase its therapeutic potential.

Objective: To discuss the potential of CAR-T cell in combination with anti PD-1 therapy for treatment of CRC.

Method: The review materials used in this paper were taken from 31 journals that meet the criteria of literature searching.

Results and Discussion: Based on previous studies, high level of IFN- $y$ and TNF- $\alpha$ secretions were found in Epithelial Cell Adhesion Molecule (EpCAM) tumor cells, showing that EpCAM-CAR-T cells have specific cytotoxic effect on target tumor cells. The average colorectal tumor volume in the EpCAM-CAR-T cell group was lower than the control group, indicating that EpCAM-CAR-T cells were able to inhibit both the formation and growth of tumor cells. On the other hand, administration of anti PD-1, nivolumab for metastasis CRC shows a durable responses and disease control, as well as long-term survival.
\end{abstract}

Conclusion: The combination of EPCAM-CAR-Tcell immunotherapy with anti PD-1 nivolumab could be an effective potential novel treatment for CRC.

Keywords: anti PD-1, CAR-T cell, colorectal cancer, immunotherapy

\section{PENDAhULUAN}

Kanker kolorektal merupakan penyakit keganasan ketiga tersering di dunia dengan 1,4 juta kasus baru yang terdiagnosis tiap tahunnya ${ }^{[1]}$. Data epidemiologi kanker kolorektal menunjukkan bahwa risiko mengalami kanker ini sebesar 1 dari 20 orang dengan risiko yang lebih rendah ditemukan pada wanita dibandingkan pria. Di Indonesia, pada tahun 2018 dilaporkan bahwa insidensi kanker kolorektal ialah sebesar 12,8 per 100.000 penduduk usia dewasa ${ }^{[2]}$.

Sekitar 9,5\% dari seluruh mortalitas kasus kanker disebabkan oleh kanker kolorektal. Kanker kolorektal adalah penyakit keganasan yang berasal dari jaringan usus besar yang terdiri dari kolon dan/atau rektum ${ }^{[2]}$. Pengobatan yang tersedia untuk kanker kolorektal saat ini meliputi operasi pada stadium awal, diikuti dengan kemoterapi dan/atau radioterapi untuk stadium lebih lanjut yang diketahui bahwa sejumlah penanganan tersebut bersifat invasif dan memiliki beberapa efek samping yang kurang menguntungkan bagi pasien $^{[3]}$. Oleh karena itu, di samping tatalaksana dengan operasi, kemoterapi, dan radioterapi, kebutuhan akan pengobatan dengan imunoterapi hadir untuk melengkapi pilar standar penanganan kanker kolorektal[ ${ }^{[4]}$.

Diantara berbagai macam pilihan imunoterapi yang sedang berkembang, Chimeric Antigen Receptor (CAR) T-cell merupakan jenis imunoterapi yang sedang populer dalam beberapa tahun terakhir terkait perkembangan terapi melawan kanker. CAR merupakan reseptor imun yang dibuat secara 
khusus di laboratorium yang mampu memodifikasi limfosit untuk menargetkan dan mengeliminasi sel yang mengekspresikan antigen spesifik pada permukaannya, sedangkan sel T, baik yang diperoleh dari darah pasien sendiri (autologous) maupun dari donor yang sehat (allogeneic) direkayasa secara genetik untuk mengekspresikan CAR yang spesifik. Oleh karena sifatnya itu, CAR-T cell kini didesain secara khusus untuk menargetkan antigen spesifik dari sel tumor, bukan sel normal yang sehat ${ }^{[5]}$, dan sejak tahun 2017, dikarenakan efektivitasnya, CAR-T cell telah disetujui oleh Food and Drug Administration (FDA) untuk pengobatan dua penyakit keganasan hematologis yakni acute lymphoblastic leukemia dan lymphoma ${ }^{[6]}$.

Walaupun hasil yang menjanjikan berhasil dicapai pada pengobatan jenis kanker hematologis, efektivitas imunoterapi $C A R-T$ cell untuk mengobati tumor padat masih terbatas ${ }^{[7]}$. Hal ini dikarenakan adanya hambatan biologis yang terdapat pada Tumor Microenvironments $(\mathrm{TME})^{[8]}$ yang terdiri atas sel imun, sitokin, dan molekul imun inhibitory beserta faktor inhibitory lainnya, selain sel tumor itu sendiri ${ }^{[9]}$. Diantara berbagai molekul imun inhibitory yang berperan, Programmed Cell Death-1 (PD-1) merupakan molekul immune checkpoint yang mampu menghambat proliferasi sel $T$ dan Tumor-Infiltrating Lymphocytes (TILs) pada jaringan perifer yang menyebabkan resistensi imun pada TME sehingga sering digunakan sebagai target terapi ${ }^{[10]}$. Terapi dengan menargetkan PD-1 yang dikenal sebagai Immune Checkpoint Inhibitor (ICI) telah terbukti efektif pada pengobatan melanoma stadium lanjut, Merkel cell carcinoma, non-small cell lung cancer, cutaneous squamous cell carcinoma, urothelial cancer, renal cancer, refractory Hodgkin lymphoma, hepatocellular carcinoma, gastric cancer, triple-negative breast cancer, dan microsatellite instability (MSI)-high tumors sehingga kini dijadikan sebagai terapi integrasi dalam regimen standar pengobatan berbagai kanker tersebut ${ }^{[11]}$.
Yeku, et. al (2017) menyatakan bahwa untuk meningkatkan luaran klinis penanganan tumor padat dengan CAR$T$ cell, perlu dilakukan modifikasi pada $C A R-T$ cell yakni menggabungkannya dengan molekul co-stimulator, ligan, terapi target, atau agen imunomodulator ${ }^{[12]}$. Lebih lanjut, sehubungan dengan efektivitas anti PD1, dalam penelitian Cherkassky et. al (2016) dijelaskan bahwa kombinasi CAR-T cell dengan anti PD-1/PD-L1 diyakini mampu meningkatkan potensi CAR-T cell dalam pengobatan tumor padat ${ }^{[13]}$. Berdasarkan konsep masalah tersebut, pada literature review ini akan dibahas mengenai potensi terapi kombinasi immunoterapi CAR-T cell dengan Immune Checkpoint Inhibitor, khususnya anti PD-1/PD-L1 sebagai pilihan terapi terbaru dalam pengobatan kanker kolorektal.

\section{METODE}

Literature review ini disusun menggunakan metode studi pustaka dengan mengumpulkan dan menganalisis berbagai referensi yang valid terkait potensi terapi kombinasi imunoterapi CAR-T cell dengan Immune Checkpoint Inhibitor (ICI) khususnya anti PD-1 sebagai pilihan pengobatan terbaru kanker kolorektal. Data statistik pada literature review ini bersumber dari laman resmi Kemenkes RI dan WHO. Adapun sebagian besar jurnal diperoleh melalui database PubMed dengan kata kunci pencarian berupa $C A R-T$, colorectal cancer, dan anti $P D-1$ sehingga ditemukan total 66 jurnal penelitian publikasi 10 tahun terakhir yang relevan dengan kata kunci dan hanya 31 jurnal yang memenuhi kriteria untuk dikaji lebih lanjut.

\section{PEMBAHASAN}

\subsection{Chimeric Antigen Receptor (CAR) T-cell Therapy}

Tujuan utama dari penelitian $C A R$ $T$ cell adalah untuk menemukan fungsi aktif dari limfosit $T$ dalam menargetkan dan membunuh sel kanker. Terapi $C A R$ $T$ cell berkerja dengan memanipulasi sistem imun, yakni sel $T$ direkayasa secara genetik untuk mengekspresikan imunoreseptor (CAR) khusus yang 
kemudian memberikan kemampuan bagi sel $\mathrm{T}$ tersebut untuk menargetkan protein spesifik pada sel kanker. Misalnya, CD19 CAR-T cell telah didesain untuk mengekspresikan CAR spesifik antigen CD-19 yang keduanya ditemukan berperan dalam kejadian limfoma dan leukimia. Berbeda dengan struktur reseptor sel $\mathrm{T}$ klasik yang memiliki rantai alfa dan beta intraseluler ganda yang dihubungkan oleh kompleks CD3 dan dilengkapi dengan Major Histocompatibility Complex (MHC), reseptor pada CAR memiliki domain ekstraseluler yang terdiri atas singlechain variable fragment (scFv) dan tidak memerlukan MHC untuk menargetkan antigen spesifik pada sel kanker ${ }^{[14]}$.

Terapi CAR-T cell merupakan metode imunoterapi terpersonalisasi yang memiliki langkah-langkah tertentu untuk implementasinya dalam dunia medis. Untuk lebih jelasnya, proses keseluruhan terdiri dari ekstraksi sel $\mathrm{T}$ normal dari darah perifer pasien yang diperoleh melalui leukopheresis, kemudian imunoreseptor khusus (CAR) diintegrasikan ke sel $\mathrm{T}$ tersebut di laboratorium, lalu diikuti oleh proses in vitro untuk pembibitan dan penggandaan CAR-T cell. Terakhir, $C A R-T$ cell yang telah diperbanyak kemudian dimasukkan kembali ke tubuh pasien secara intravena sambil memantau efek samping akut pengobatan seperti demam tinggi, kesulitan bernapas, mual muntah berat, dan nyeri otot serta nyeri sendi yang merupakan gejala-gejala dari Cytokine Releases Syndrome (CRS). Setelah proses re-infus, CAR-T cell yang telah direkayasa secara khusus akan berproliferasi dan membunuh sel-sel tumor yang mengandung antigen spesifik yang menjadi sasaran $\mathrm{CAR}^{[15]}$. Untuk alur pembuatan CAR-T cell dapat dilihat pada gambar 1 .

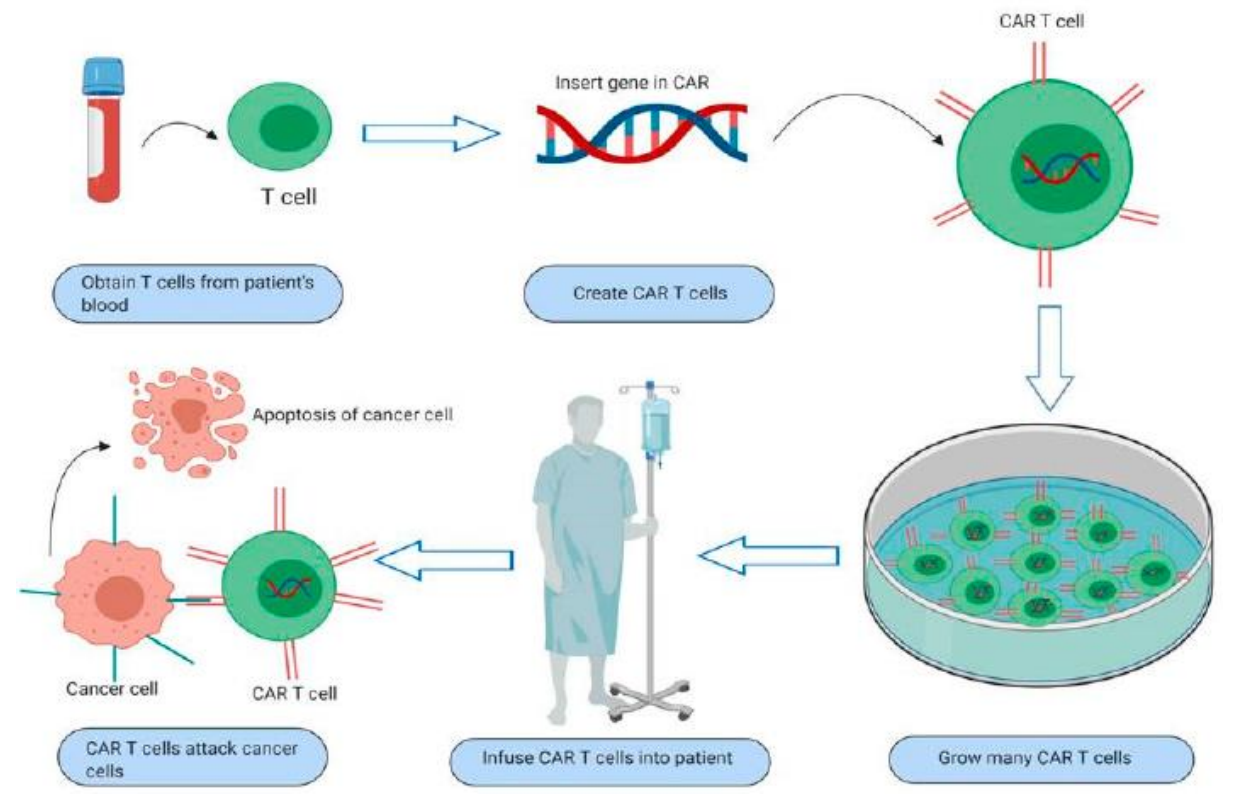

Gambar 1. Prosedur Pembuatan dan Penggunaan CAR-T cell Selaku Imunoterapi ${ }^{[15]}$

Berdasarkan struktur dan metode produksinya, telah terdapat empat generasi dari CAR-T cell yang berkembang hingga saat ini. CAR-T cell generasi pertama hanya mengekspresikan molekul $\mathrm{CD} 3 \zeta$ untuk penghantaran sinyal dan dibuktikan gagal dalam berbagai penelitian ${ }^{[16]}$.
CAR-T cell generasi kedua dan ketiga selain mengekspresikan molekul CD3ろ juga diketahui memiliki molekul-molekul co-stimulatory seperti CD28, 4-1BB, OX40 dan CD27 yang berfungsi untuk memacu produksi sitokin dan merupakan CAR-T cell yang sekarang paling banyak digunakan dalam 
penelitian terkait pengobatan tumor. Sedangkan CAR-T cell generasi keempat yang memiliki tambahan struktur IL-2 dan IL-12 masih dalam tahap pengembangan lebih lanjut ${ }^{[17]}$. Struktur dari masing-masing generasi CAR T-cell dapat dilihat pada gambar 2.

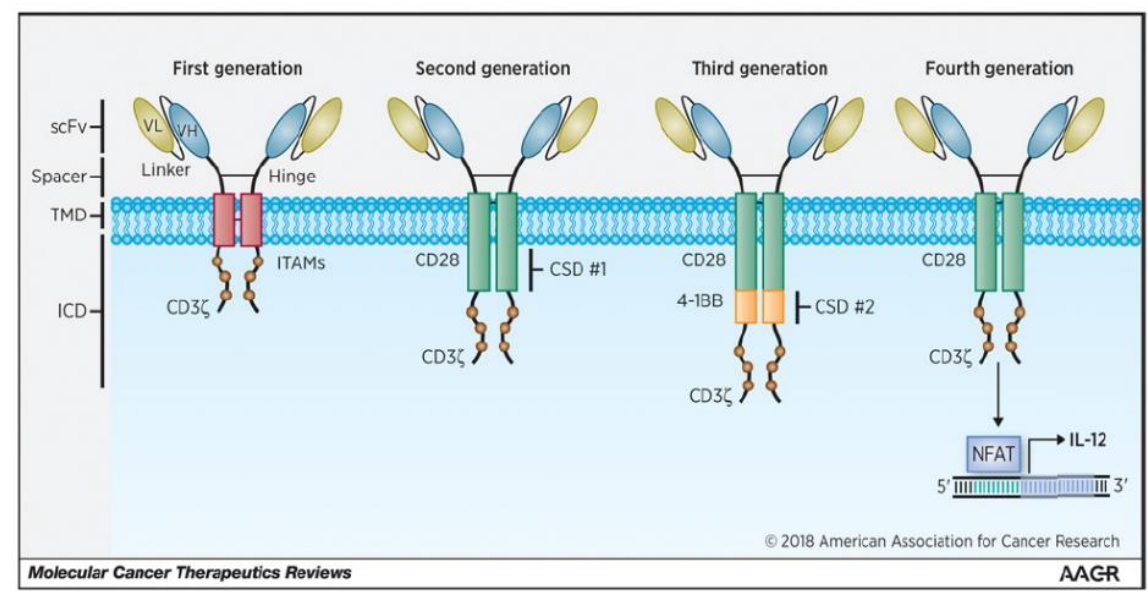

Gambar 2. Struktur CAR-T cell dari Berbagai Generasi ${ }^{[17]}$

3.2. Programmed Cell Death-1 (PD1) Selaku Target Terapi pada Tumor Microenvironment (TME)

Jaringan tumor padat yang terbentuk tidak hanya mencakup sel-sel tumor, tetapi juga sel-sel imun inhibitory (sel $\mathrm{T}$ regulator, tumor-associated macrophages, myeloid-derived suppressor cells), sitokin inhibitory (IL-4, IL-6, II-10 dan TGF- $\beta$ ), molekul imun inhibitory (PD-1, CTLA-4, LAG3, dan Tim3) dan faktor-faktor inhibitory lainnya (stress oksidatif, keterbatasan nutrisi, $\mathrm{pH}$ yang terlalu asam, dan hipoksia) yang keseluruhan komponen tersebut membentuk Tumor Microenvironment $(\mathrm{TME})^{[18]}$. TME inilah yang diduga menyebabkan penurunan infiltrasi selsel imun dan menghambat fungsi sel imun pada jaringan tumor padat sehingga berujung pada terbebasnya sel-sel tumor dari sistem kekebalan tubuh [19].

Pada kondisi fisiologis, sel $T$ bersirkulasi di seluruh tubuh untuk mengenali antigen dari patogen yang terdapat pada permukaan Antigen Precenting Cells (APCs). Perlekatan antara reseptor sel T (TCR) pada sel T helper CD4 dan sel T sitotoksik CD8 dengan antigen yang diikat oleh $\mathrm{MHC}$ pada permukaan APC merupakan sinyal pertama untuk aktivasi sel $\mathrm{T}$ selama respon imun berlangsung. Selain itu, sel $\mathrm{T}$ membutuhkan beberapa sinyal sekunder dari reseptor co-stimulatory agar bisa teraktivasi. Interaksi antara reseptor co-stimulatory tersebut dengan ligannya pada APC mengakibatkan transmisi sinyal aktivasi maupun toleransi pada sel $\mathrm{T}^{[18]}$.

Molekul co-stimulatory pada sel $\mathrm{T}$ meliputi CD28 dan Inducible T Cell CoStimulator (ICOS) yang masing-masing berikatan dengan $\mathrm{B} 7-1$ (CD80) atau B72 (CD86) pada permukaan APC dan ligan ICOS (ICOSL). Sebaliknya, molekul co-inhibitory pada sel $\mathrm{T}$ diantaranya Cytotoxic $T$ Lymphocyte Antigen 4 (CTLA-4) dan Programmed Cell Death-1 (PD-1) atau (CD 279). PD1 berikatan dengan ligannya yakni PDL1 (B7-H1/CD274) yang terdapat pada sel target, termasuk sel tumor ${ }^{18}$. Sel tumor dan beberapa sel stroma yang terkait dapat mengekspresikan PD-L1 yang distabilkan oleh Tumor Necrosis Factor Alpha (TNF- $\alpha$ ) [19] dan menyebabkan penekanan pada imunitas anti-tumor ${ }^{[20]}$. Selama aktivasi sel T, PD-1 terekspresikan pada permukaan sel $T$ dan menyebabkan kelelahan pada sel T. Ekspresi PD-1 juga ditemukan pada permukaan limfosit $B$ dan sel Natural Killer (NK), namun secara dominan, lebih mempengaruhi ekspresi 
sel T CD8 selaku garis pertahanan pertama melawan sel tumor ${ }^{[21]}$. Pada kondisi normal, ekspresi dari PD-1 memiliki aktivitas utama berupa transmisi sinyal penghambat (inhibitory) selama respon imun sel T berlangsung. Hal ini terjadi melalui mekanisme downregulation dari Casein Kinase 2 (CK 2) yang berperan dalam fosforilasi domain regulatorik dari protein PTEN (phosphatase and tensin homologue deleted on chromosome 10) dan menyebabkan terminasi secara bertahap dari aktivitas phosphoinositide 3-kinase (PI3K) yang akhirnya menghambat Cyclin-Dependent Kinase (CDK) dan mengontrol tingkat ekspresi dari reseptor di permukaan sel $\mathrm{T}^{[22]}$. Mekanisme kerja PD-1 dalam menghambat aktivitas sel T dapat dilihat pada gambar 3.

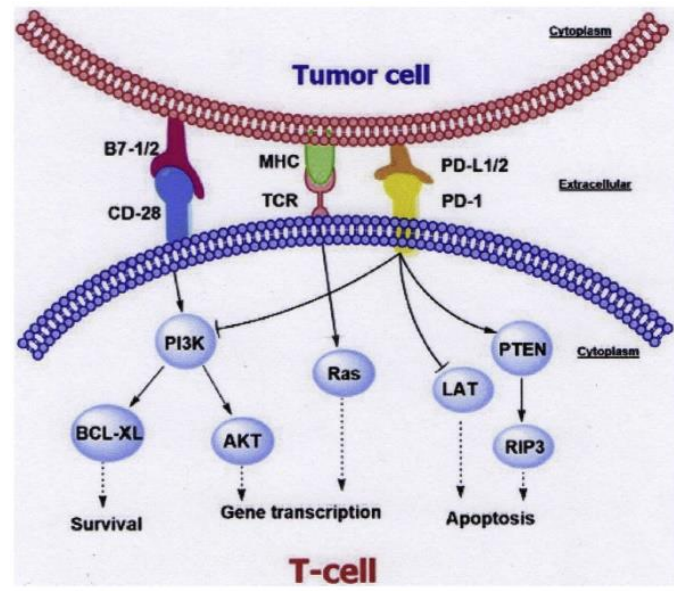

Gambar 3. Mekanisme Kerja PD-1 dalam Menghambat Aktivitas Imun Sel $\mathrm{T}^{3}$

\subsection{Potensi Epithelial Cell Adhesion Molecule-Chimeric Antigen Receptor-modified $T$ cells (EPCAM- CAR-T cells) sebagai Imunoterapi Terbaru Kanker Kolorektal}

Seperti yang telah diketahui, terapi $C A R-T$ cell bekerja berdasarkan hasil rekayasa genetik sel $T$ untuk mengekspresikan imunoreseptor (CAR) khusus yang bertujuan untuk memberikan kemampuan bagi sel $\mathrm{T}$ tersebut untuk menargetkan protein spesifik pada sel tumor. Pemilihan imunoreseptor (CAR) khusus sangat berperan dalam tingkat kesuksesan terapi CAR-T cell ${ }^{14}$. Saat ini, salah satu kandidat antigen target pada sel kanker kolorektal dengan terapi CAR-T cell ialah Epithelial Cell Adhesion Molecule $\left(\right.$ EpCAM) ${ }^{[23]}$.

Saat ini EpCAM lebih dikenal sebagai biomarker untuk Circulating Tumor Cells (CTCs) dan Cancer Stem Cells (CSCs). Diketahui pula bahwa EpCAM turut berperan dalam proliferasi, survival dan metastasis sel kanker. EpCAM merupakan glikoprotein transmembran yang dapat ditemukan pada sel kanker kolorekta[l[24]. Zhang et.al (2019) berhasil membuktikan bahwa ekspresi EpCAM yang lebih tinggi ditemukan pada sel kanker kolorektal HT29 dan SW480 jika dibandingkan dengan sel human nonsmall cell lung cancer (NSCLC) A549 dan kanker payudara MDAMB231 yang tercatat hanya memiliki ekspresi EpCAM moderat dan sel kanker serviks hela yang tidak memiliki ekspresi EpCAM sama sekali. Melihat potensi tersebut, Zhang et. al kemudian melanjutkan penelitian untuk menguji efek antitumor CAR-T cell terhadap perkembangan kanker kolorektal dengan menggunakan EpCAM sebagai target reseptor spesifik dari CAR-T cell. Pada penelitian berbasis in vivo, zhang et al menggunakan CAR-T cell generasi ketiga yang reseptornya telah dimodifikasi menggunakan EpCAM dengan lentivirus sebagai vektornya pada tikus betina NOD/SCID BALB/C (usia 5-8 minggu) yang telah diinduksi dengan sel kanker kolerektal HT29 dan SW 480[23].

EpCAM-CAR-T cell generasi ketiga tersebut kemudian dikonstruksi dengan komponen sinyal peptida dari hIL-2, anti-EpCAM scFv, CD8 $\alpha$-hinge, CD8 $\alpha$ transmembran (CD8 $\alpha-T M), \quad$ costimulatory CD28 dan 4-1BB, serta human $\mathrm{CD} 3 \zeta$ domain (gambar 4a dan 4b). scFv memiliki peran untuk berikatan dengan antigen sel tumor. CD8 $\alpha$-hinge berperan dalam dimerisasi CAR. CD8aTM berfungsi melekatkan CAR pada membran limfosit. CD28 dan 4-1BB merupakan molekul co-stimulatory yang dapat meningkatkan potensi aktivitas sitotoksik dan kapasitas proliferasi sel $\mathrm{T}$ serta memperpanjang waktu masa 
hidup sel $\mathrm{T}^{[25]}$. Terakhir, CD3ろ berperan dalam transmisi sinyal yang dihasilkan oleh ikatan antigen dengan scFv. Gen EpCAM-CAR-T cell yang telah terbentuk kemudian disisipkan ke dalam vektor lentivirus pWPXLD dengan menggunakan enzim BamHI dan EcoRI (gambar 4c). ${ }^{[23]}$

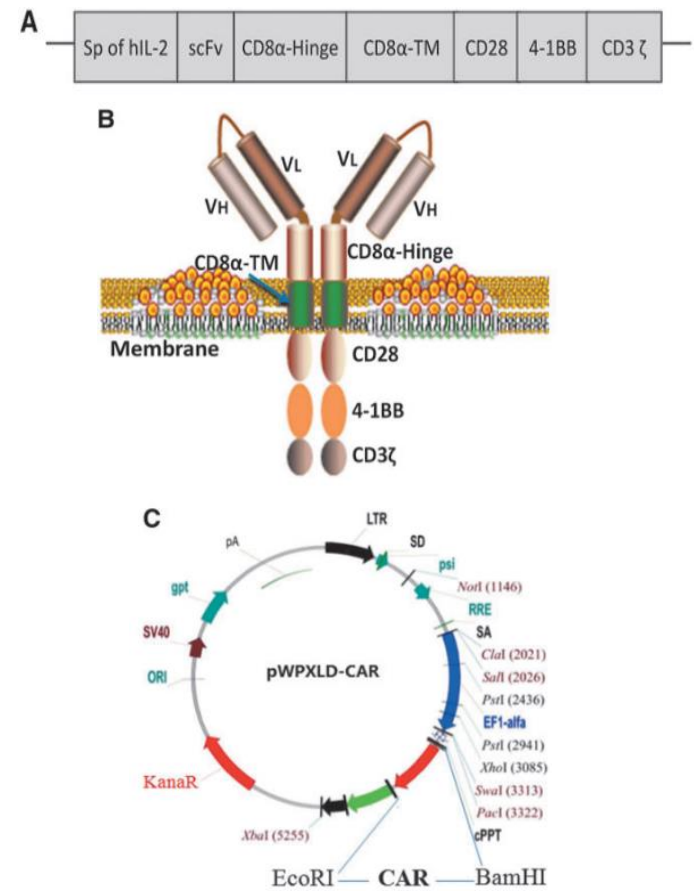

Gambar 4. Konstruksi Epithelial Cell Adhesion Molecule (EpCAM)-Spesific Chimeric Antigen Receptor (CAR) T- cell (A dan B) dan Penyisipan Gen EPCAM$C A R-T$ cell pada Vektor Lentiviral $(C)^{[23]}$

Sehubungan dengan pengujian potensi EpCAM-CAR-T cell dalam mengobati kanker kolorektal, Zhang, et. al kemudian membagi penelitiannya ke dalam dua aspek pengujian, yakni efek sitotoksik dan antitumor EpCAM- CAR-T cell terhadap sel kanker kolorektal yang diujikan ${ }^{[23]}$.

\subsubsection{EpCAM-CAR-T Meningkatkan Efek Sititoksik Spesifik terhadap Sel Target EpCAM Dependen}

Dalam rangka mengetahui kemampuan EpCAM-CAR-T cell dalam mengenali tumor spesfik pengekspresi EpCAM, maka Zhang et al (2019) menginkubasikan EPCAM-CAR-T cell pada berbagai jenis sel tumor dengan tingkat ekspresi EpCAM berbeda-beda seperti yang telah disebutkan di atas (Effector:Target /E:T ratio=5). Dua puluh jam setelah inkubasi, jumlah sitokin yag disekresikan oleh efektor yaitu IFN-y dan TNF- $\alpha$ kemudian diukur dengan ELISA. Hasilnya kemudian dibandingkan dengan kelompok kontrol MOCK T (No-CAR) cel[i[3].
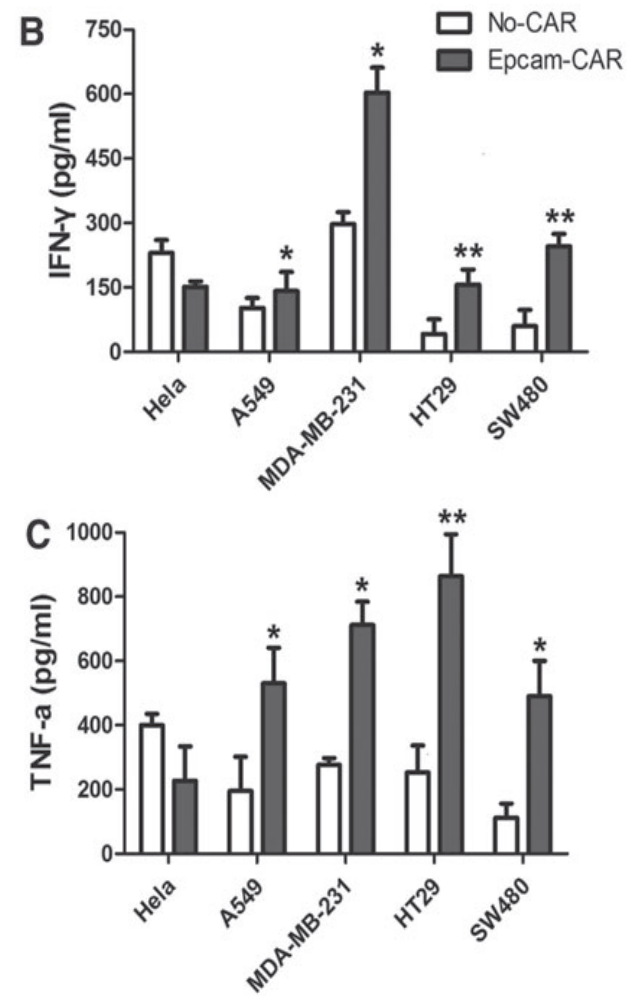

Grafik 1. Perbandingan EpCAM-CAR-T cell dan No-CAR T-cell dalam Sekresi IFN- $y$ dan TNF- $\alpha$ pada Berbagai Jenis Sel Tumor dengan Tingkat Ekspresi Reseptor EpCAM yang Berbeda ${ }^{[23]}$

Dalam penelitian tersebut diperoleh hasil bahwa CAR-T cell mampu secara spesifik mengenali sel-sel tumor dengan ekpresi EpCAM positif (A549, MDA-MB231, SW480 dan HT29). Hal ini diketahui melalui sekresi IFN- $y$ dan TNF- $\alpha$ dalam jumlah yang tinggi pada EPCAM-CAR-T cell dibandingkan dengan MOCK $T$ (No-CAR) cell pada jenis sel kanker kolorektal HT29 dan SW480, sel NSCLC A549 serta sel kanker payudara MDA-MB-231 ( $<<0,05$ $=$ A549, MDA-MB-231; P $<0,01=$ SW480, HT29), yang mana diketahui bahwa IFNY dan TNF- $\alpha$ merupakan sitokin proinflamasi yang dilepaskan oleh sel $\mathrm{T}$ 
sebagai respon melawan sel tumor maupun patogen. Sedangkan pada sel tumor dengan ekspresi EpCAM negatif (Hela), tidak ditemukan adanya perbedaan signifikan level sekresi IFN-Y dan TNF- $\alpha$ antara kelompok EpCAMCAR-T cell dan kelompok No-CAR T. Berdasarkan temuan ini, Zhang et al (2019) menegaskan bahwa EPCAM$C A R-T$ cell mampu bekerja secara spesifik dengan menargetkan EpCAM pada permukaan sel tumor (Grafik 1) ${ }^{[23]}$.

Selanjutnya, untuk menguji kemampuan sitotoksik EpCAM-CAR-T cell terhadap sel kanker kolorektal, dilakukan evaluasi kadar sitotoksisitas pasca terapi EpCAM-CAR-T cell menggunakan ${ }^{51} \mathrm{Cr}$ release assay secara in vitro. Rasio jumlah EpCAMCAR-T cell terhadap sel tumor direpresentasikan oleh Effector:Target $(E: T)$ ratio yang mana sampel dengan

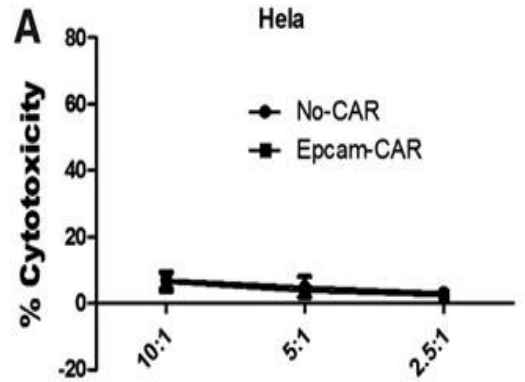

E:T ratio

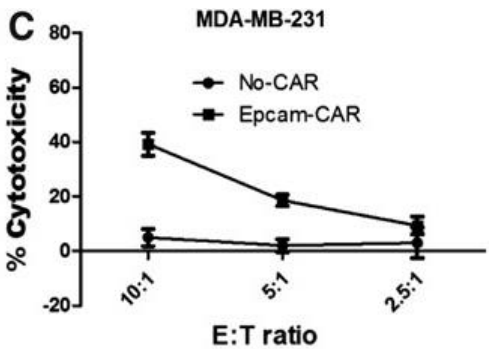

E:T ratio yang lebih besar akan memiliki konsentrasi EpCAM-CAR-T cell yang lebih tinggi (10:1>5:1>2,5:1). Hasilnya, tampak bahwa efek sitotoksik litik pada EpCAM-CAR-T cell meningkat seiring dengan bertambahnya jumlah ekspresi EpCAM pada sel kanker kolorektal HT29 dan SW480, sedangkan pada sel tumor EpCAM negatif (Hela), tidak ditemukan adanya aktivitas sitotoksik yang signifikan dari EPCAM-CAR-T cell (Grafik 2). Hal ini membuktikan bahwa EpCAM-CAR-T cell secara spesifik memiliki efek sitotoksik litik terhadap sel kanker kolorektal yang efektivitasnya bertambah seiring dengan makin banyaknya efektor ( $C A R-T$ cell) yang bekerja selama respon imun berlangsung ${ }^{[23]}$.

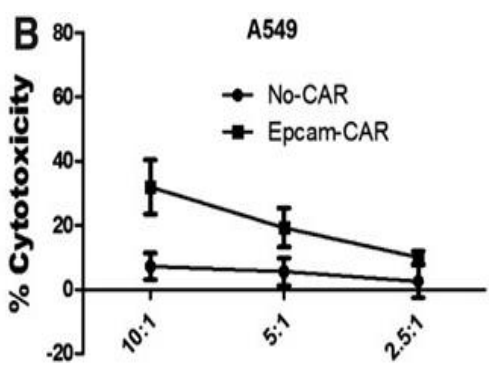

E:T ratio
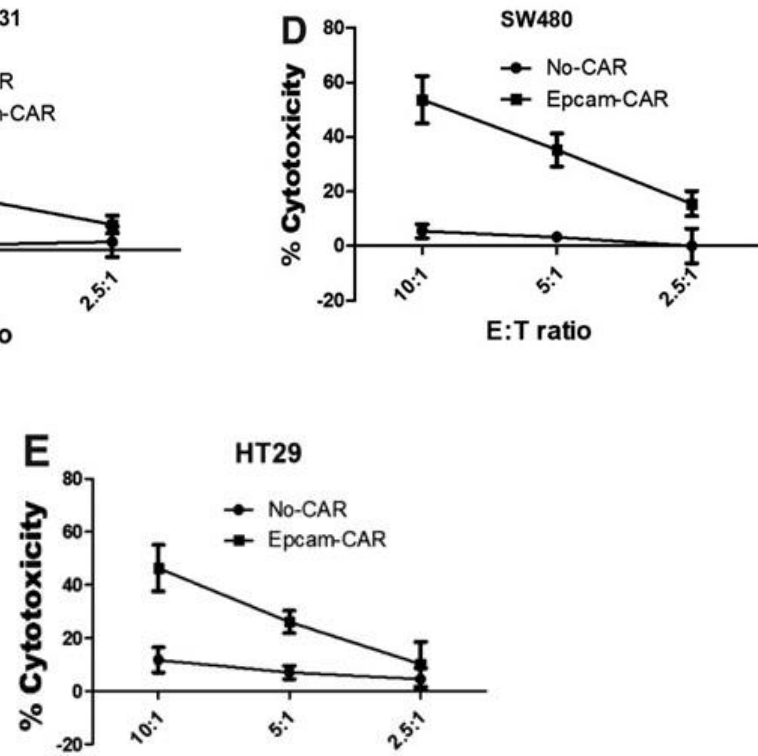

E:T ratio 
Grafik 2. Efek Sitotoksik Litik EpCAM-CAR-T cell pada Berbagai Jenis Sel Tumor dengan Tingkat Ekspresi Reseptor EpCAM yang Berbeda ${ }^{[23]}$.

\subsubsection{EpCAM-CAR-T Menghambat Pertumbuhan Tumor pada Tikus dengan Kanker Kolorektal \\ Untuk mengetahui kemampuan} EPCAM-CAR-T cell dalam menghambat pertumbuhan tumor secara in vivo, dua jenis sel tumor kanker kolorektal dengan ekspresi EpCAM yang tinggi, yaitu HT29 dan SW 480 dipilih sebagai model tumor xenograf. Kemudian sebanyak $5 \times 10^{6}$ sel tumor diinokulasikan pada tikus NOD/SCID BALB/c. Hewan uji coba tersebut lalu dibagi menjadi 3 kelompok perlakuan dengan masing-masing diberikan $2 \times 10^{7}$ EpCAM-CAR-T cell, MOCK T-cell dan normal saline (NS group) secara bersamaan ketika sel tumor diinokulasikan pada tikus. Ukuran volume tumor kemudian diukur dengan kaliper pengukur tiap 3 hari setelah tumor mulai teraba[ ${ }^{[23]}$. Untuk hasil pengukuran volume tumor dapat dilihat pada grafik 3.

Berdasarkan grafik 3, terlihat bahwa pada hari ke 26 rata-rata volume tumor kolorektal HT29 pada kelompok yang diberi EpCAM-CAR-T cell yaitu $313 \pm 92$ $\mathrm{mm}^{3}$. Hasil ini secara signifikan berbeda dibandingkan dengan kelompok yang diberi MOCK T-cell dengan volume mencapai $725 \pm 125 \mathrm{~mm}^{3}$ dan $800 \pm 170$ $\mathrm{mm}^{3}$ pada tikus yang diberi normal saline $(p<0,05)$. Hal serupa juga didapatkan pada tikus yang diinduksi dengan sel kanker kolorektal SW480. Terlihat pada grafik bahwa pada hari ke 32 rata-rata volume tumor kolorektal SW480 pada kelompok yang diberi EpCAM-CAR-T cell yaitu $159 \pm 73 \mathrm{~mm}^{3}$. Hasil ini secara signifikan berbeda dibandingkan dengan kelompok yang diberi MOCK T-cell dengan volume mencapai $407 \pm 75 \mathrm{~mm}^{3}$ dan $710 \pm 108$ $\mathrm{mm}^{3}$ pada tikus yang diberi normal saline $(p<0,05)$. Berdasarkan hasil tersebut, Zhang et al (2019) menyimpulkan bahwa EpCAM-CAR-T cell mampu menghambat pembentukan dan pertumbuhan kanker kolorektal HT29 dan SW480 secara signifikan pada model xenograf ${ }^{[23] \text {. }}$
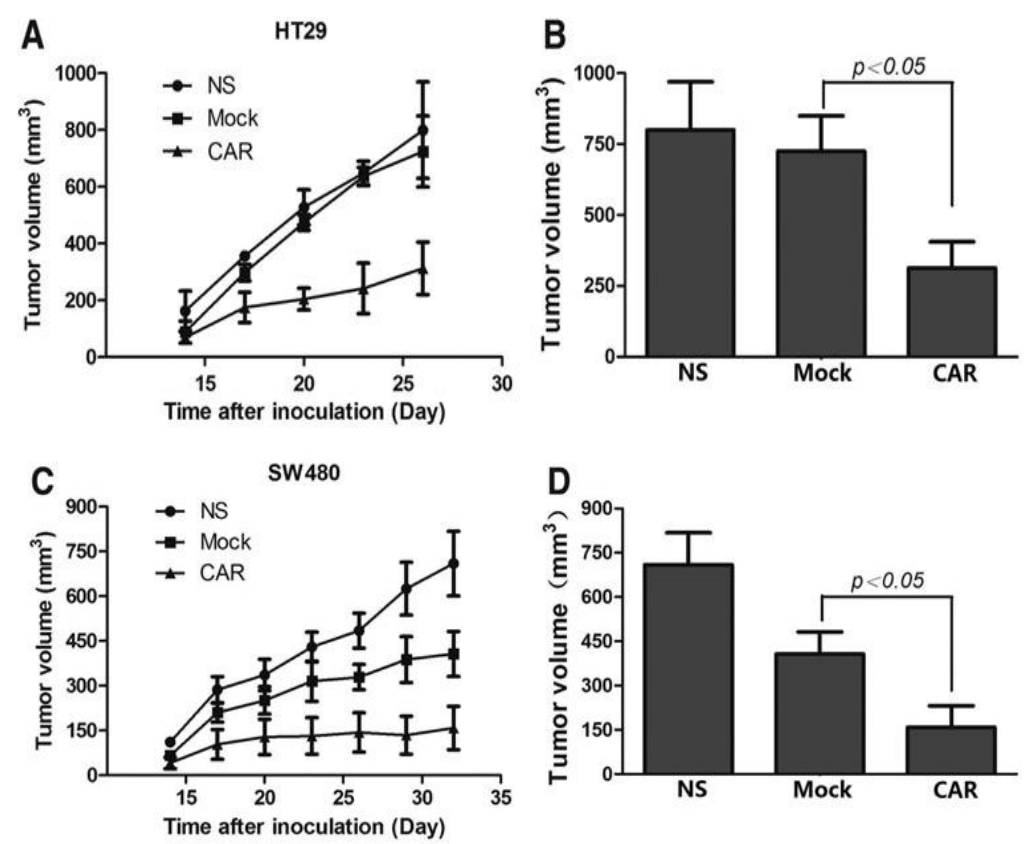

Grafik 3. Kemampuan EPCAM-CAR-T cell dalam Menghambat Pertumbuhan Tumor pada Tikus dengan Kanker Kolorektal. Volume Tumor Diukur Tiap 3 Hari (A dan C). Rerata Volume Tumor pada Akhir Perlakuan (B dan D) ${ }^{[23]}$ 


\subsection{Peran anti PD-1 (Nivolumab) Sebagai Immune Checkpoint Inhibitor pada Terapi Kanker Kolorektal Metastasis}

Saat ini, standar perawatan untuk pasien kanker kolorektal metastasis (mCRC) yang tidak memenuhi syarat pembedahan ialah dengan terapi paliatif menggunakan regimen kemoterapi berbasis fluorouracil dengan kombinasi anti-angiogenesis atau anti-epidermal growth factor receptor ${ }^{[26]}$. Meskipun dengan sejumlah pilihan terapi sistemik mCRC yang tersedia, tingkat survival sampai 5 tahun hanya sekitar $13,5 \%[27]$. Hal ini erat kaitannya dengan sifat kanker kolorektal yang merupakan salah satu bentuk kanker yang ditandai oleh berbagai macam kelainan genetik dan epigenetik. Salah satu penyebab utama dari hipermutasi pada kanker kolorektal adalah adanya defisit dari sistem Mismatch Repair Deficient (dMMR) DNA yang mengakibatkan terbentuknya Microsatellite Instability-High (MSI-H) tumor yang secara kuat mengekspresikan protein immunological checkpoint, termasuk Programmed cell death-1(PD-1) ${ }^{[28]}$.

Bukti terbaru menyebutkan bahwa pasien dengan tipe mCRC DNA $\mathrm{dMMR} /(\mathrm{MSI}-\mathrm{H})$ merupakan kelompok yang hanya sedikit menerima manfaat dari kemoterapi konvensional dan memiliki overall survival (OS) yang lebih pendek dibanding pasien dengan tipe mCRC proficient MMR (pMMR) ${ }^{[29]}$ oleh karena beban mutasi dan kelebihan neoantigen tumor beserta infiltrasi sel imun yang lebih padat ${ }^{[30]}$. Sehubungan dengan itu, dalam rangka mengatasi masalah yang ditimbulkan oleh interaksi PD-1/PD-L1 sekaligus mengurangi kasus rekurensi pada kelompok tumor ini, pengobatan berbasis imunoterapi dengan menargetkan PD-1 pada sel imun dinilai dapat memberikan keuntungan ${ }^{[28]}$. Potensi terapi anti PD-1 tersebut kemudian mendorong Overman et. al untuk melakukan penelitian yang berfokus pada analisis potensi anti PD1 , yakni nivolumab dalam mengobati kanker kolorektal metastasis tipe dMMR MSI-H[31].

Dalam penelitian multicenter openlabel nonrandomized yang dilakukan oleh Overman et al, sebanyak 53 pasien (umur $\geq 18$ tahun) terkonfirmasi mCRC rekuren dengan tipe dMMR/MSI-H yang telah menerima terapi sebelumnya diberikan perlakuan berupa pemberian nivolumab sebanyak $3 \mathrm{mg} / \mathrm{kgBB}$ tiap 2 minggu. Respon terapi kemudian mulai diukur pada 28 hari setelah dosis pertama, tiap 6 minggu selama 24 minggu dan tiap 12 minggu setelahnya menggunakan analisis penilaian RESCIST v1.1. Hasilnya dapat dilihat pada tabel di bawah ${ }^{[31]}$.

Tabel 1. Respon Pengobatan Nivolumab pada mCRC Tipe $\mathrm{dMMR} / \mathrm{MSI}-\mathrm{H}^{[31]}$

\begin{tabular}{lc}
\hline \multicolumn{1}{c}{$\begin{array}{c}\text { Patients } \\
\mathrm{n}(\%)\end{array}$} & $\begin{array}{c}\text { dMMR/MSI-H } \\
\text { per central } \\
\text { assessment } \\
(\mathrm{N}=53)\end{array}$ \\
\hline $\begin{array}{l}\text { Objective response } \\
\text { rate }\end{array}$ & $19(35.8)$ \\
[95\% Cl] & {$[23.1-50.2]$} \\
Best overall response & \\
$\quad$ Complete & 0 \\
response & $19(35.8)$ \\
Partial response & $20(37.0)$ \\
Stable disease & $11(20.8)$ \\
Progressive & disease \\
$\quad$ Not determined & $3(5.7)$ \\
Disease control for & $39(73.6)$ \\
$\geq 12$ weeks [95\% Cl] & {$[59.7-84.7]$} \\
\hline
\end{tabular}

Berdasarkan tabel 1, dari 53 pasien kanker kolorektal metastasis/rekuren yang terkonfirmasi MSI-H/dMMR, diketahui bahwa objective response rate (ORR) dan disease control rate untuk $\geq 12$ minggu masing-masing sebesar $35 \cdot 8 \% \quad(95 \%$ Cl $23 \cdot 1 \%-50 \cdot 2 \%)$ dan $73,6 \% \quad(95 \%$ Cl 59.7-84.7). Berdasarkan hasil tersebut, overman et al menyatakan bahwa pasca pemberian nivolumab, respon terapi yang cukup signifikan ditemukan disertai pengendalian penyakit dalam jangka panjang dengan masa survival bagi pasien mCRC tipe dMMR/MSI-H yang lebih lama sehingga dapat dijadikan sebagai opsi terbaru dalam terapi pasien mCRC tipe dMMR/MSI-H dan melengkapi terapi lain yang telah $\mathrm{ada}^{[31]}$. 


\section{KESIMPULAN}

Kombinasi imunoterapi CAR-T cell dengan Immune Checkpoint Inhibitor khususnya anti PD-1 memiliki potensi yang menjanjikan sebagai pilihan terapi terbaru pengobatan kanker kolorektal. EpCAM merupakan glikoprotein transmembran yang ekspresinya banyak ditemukan pada sel kanker kolorektal sehingga tepat untuk dijadikan target pengobatan CAR-T cell. Imunoterapi berbasis EpCAM-CAR-T cell diketahui terbukti secara spesifik memiliki efek sitotoksik litik terhadap sel kanker kolorektal dan secara efektif mampu menekan pembentukan dan

\section{DAFTAR PUSTAKA}

1. Arnold M., Sierra M. S., Laversanne M., Soerjomataram I., Jemal A., Bray F. Global patterns and trends in colorectal cancer incidence and mortality. Gut. 2016;66(4):683-691.

2. Komite Penanggulangan Kanker Nasional Departemen Kesehatan Republik Indonesia. Pedoman Nasional Pelayanan Kedokteran Tata Laksana Kanker Kolorektal. 2018. http://kanker.kemkes.go.id/guidelines /PNPKkolorektal.pdf

3. Neda Yaghoubia, Arash Soltania, Kiarash Ghazvinib, Seyed Mahdi Hassaniana, Seyed Isaac Hashemyc. PD-1/ PD-L1 blockade as a novel treatment for colorectal cancer. Biomedicine \& Pharmacotherapy 110 (2019) 312-318.

4. Tang J, et al. Trial watch: The clinical trial landscape for PD1/PDL1 immune checkpoint inhibitors. Nat. Rev. Drug Discov. 2018;17:854-855.

5. Sermer, D.; Brentjens, R. CAR T-cell therapy: Full speed ahead. Hematol. Oncol.2019, 37 (Suppl. 1), 95-100

6. Tomuleasa, C.; Fuji, S.; Berce, C.; Onaciu, A.; Chira, S.; Petrushev, B.; Micu, W.T.; Moisoiu, V.; Osan, C.; Constantinescu, C.; et al. Chimeric Antigen Receptor T-Cells for the Treatment of B-Cell Acute Lymphoblastic Leukemia. Front. Immunol.2018, 9, 239

7. Newick K, O'Brien S, Moon E, Albelda SM. CAR T cell therapy for solid tumors. Annu Rev Med. pertumbuhan sel tumor target. Efektivitas CAR-T cell dapat dihambat oleh molekul imun inhibitory anti PD-1 pada Tumor Microenvironment (TME) kanker kolorektal. Nivolumab, selaku agen anti PD-1 terbukti efektif dalam pengendalian penyakit kanker kolorektal khususnya tipe metastasis sebab mampu memberikan masa survival pasien yang lebih panjang. Melalui kombinasi EPCAM-CAR-T cell dengan agen anti PD-1 nivolumab yang bersifat lebih spesifik dan terpersonalisasi, maka dapat diperoleh metode pengobatan terbaru kanker kolorektal yang lebih efektif dan minim efek samping.

2017;68:139-152. 10.1146/annurevmed-062315-120245

8. Migliorini D, Dietrich P-Y, Stupp R, Linette GP, Posey $A D$, June $C H$. $C A R T$-cell therapies in glioblastoma: a first look. Clin Cancer Res. 2018;24:535-540.

9. Klemm F, Joyce JA. Microenvironmental regulation of therapeutic response in cancer. Trends Cell Biol. 2015;25:198-213.

10. Hamid O., Robert C., Daud A., et al. Safety and tumor responses with lambrolizumab (anti-PD-1) in melanoma. New England Journal of Medicine. 2013;369(2):134-144.

11.Y. Xiao, G.J. Freeman. The microsatellite instable subset of colorectal cancer is a particularly good candidate for checkpoint blockade immunotherapy. Cancer Discov. 5 (2015) 16-18.

12. Yeku, O.; Li, X.; Brentjens, R.J. Adoptive T-Cell Therapy for Solid Tumors. Am. Soc. Clin. Oncol. Educ. Book2017, 37, 193-204,

13. Cherkassky, L.; Morello, A.; VillenaVargas, J.; Feng, Y.; Dimitrov, D.S.; Jones, D.R.; Sadelain, M.; Adusumilli, P.S. Human CAR T cells with cell-intrinsic $P D-1$ checkpoint blockade resist tumor-mediated inhibition. J. Clin. Investig. 2016, 126, 3130-3144.

14.June, C.H.; Sadelain, M. Chimeric Antigen Receptor Therapy. New 
Engl. J. Med.2018, 379, 64-73, doi:10.1056/NEJMra1706169.

15.Brudno, J.N.; Kochenderfer, J.N. Chimeric antigen receptor $T$-cell therapies for lymphoma. Nat. Rev. Clin. Oncol.2018, 15, 31-46, doi:10.1038/nrclinonc.2017.128.

16. Thistlethwaite, F.C.; Gilham, D.E.; Guest, R.D.; Rothwell, D.G.; Pillai, M.; Burt, D.J.; Byatte, A.J.; Kirillova, N.; Valle, J.W.; Sharma, S.K.; et al. The clinical efficacy of firstgeneration carcinoembryonic antigen (CEACAM5)-specific CAR T cells is limited by poor persistence and transient pre-conditioning-dependent respiratory toxicity. Cancer Immunol. Immunother.2017, 66, 1425-1436, doi:10.1007/s00262-017-2034-7.

17.Yeku, O.O.; Brentjens, R.J. Armored CAR T-cells: Utilizing cytokines and pro-inflammatory ligands to enhance CAR T-cell anti-tumour efficacy. Biochem. Soc. Trans.2016, 44, 412418, doi:10.1042/BST20150291.

18.H. Rezaeeyan, S.N. Hassani, M. Barati, M. Shahjahani, N. Saki. PD1/PD-L1 as a prognostic factor in leukemia. J.Hematopathol. 10 (2017) 17-24.

19.Tang H, Qiao J, Fu YX. Immunotherapy and tumor microenvironment. Cancer Lett. 2016;370:85-90.

10.1016/j.canlet.2015.10.009

20.S.-O. Lim, C.-W. Li, W. Xia, J.-H. Cha, L.-C. Chan, Y. Wu, S.-S. Chang, W.-C. Lin, J.- M. Hsu, Y.-H. Hsu. Deubiquitination and stabilization of $P D-L 1$ by CSN5. Cancer Cell 30 (2016) 925-939.

21.V.R. Juneja, K.A. McGuire, R.T. Manguso, M.W. LaFleur, N. Collins, W.N. Haining, G.J. Freeman, A.H. Sharpe. PD-L1 on tumor cells is sufficient for immune evasion in immunogenic tumors and inhibits CD8 T cell cytotoxicity. J. Exp. Med. 214 (Apr. (4)) (2017) 895-904 jem. 20160801.

22.A.O. Kamphorst, A. Wieland, T. Nasti, S. Yang, R. Zhang, D.L. Barber,B.T. Konieczny, C.Z. Daugherty, L. Koenig, K. Yu, G.L. Sica, A.H. Sharpe, G.J. Freeman, B.R. Blazar, L.A. Turka, T.K.
Owonikoko, R.N. Pillai, S.S. Ramalingam, K. Araki, R. Ahmed. Rescue of exhausted CD8 T cells by $P D$-1- targeted therapies is CD28dependent. Science 355 (2017) 1423-1427.

23.Zhang BL, Li D, Gong YL, Huang Y, Qin DY, Jiang L, Liang $X$, Yang $X$, Gou HF, Wang YS, Wei YQ. Preclinical Evaluation of Chimeric Antigen Receptor-Modified T Cells Specific to Epithelial Cell Adhesion Molecule for Treating Colorectal Cancer. Human gene therapy. 2019 Apr 1;30(4):402-12.

24.Nubel T, Preobraschenski J, Tuncay $\mathrm{H}$, et al. Claudin- 7 regulates EpCAM-mediated functions in tumor progression. Mol Cancer Res 2009;7:285-299

25.Song DG, Ye Q, Carpenito C, et al. In vivo persistence, tumor localization, and antitumor activity of $C A R$-engineered $T$ cells is enhanced by costimulatory signaling through CD137 (4-1BB). Cancer Res 2011;71:4617-4627.

26.26. NCCN Clinical Practice Guidelines in Oncology. colon cancer V1.2017 (https://www.nccn.org/).

27.National Cancer Institute. Surveillance, Epidemiology, and End Results Program. Cancer stat facts: colon and rectum cancer http://seer.cancer.gov/statfacts/html/c olorect.html (accessed January 13, 2017)

28. Pardoll D. M. The blockade of immune checkpoints in cancer immunotherapy. Nature Reviews Cancer. 2012;12(4):252-264. doi: $10.1038 / \mathrm{nrc3239}$

29. Goldstein J, Tran B, Ensor J, et al. Multicenter retrospective analysis of metastatic colorectal cancer (CRC) with high-level microsatellite instability (MSI-H). Ann Oncol 2014; 25: 1032-8. [PubMed: 24585723]

30. Giannakis M, Mu XJ, Shukla SA, et al. Genomic correlates of immunecell infiltrates in colorectal carcinoma. Cell Rep 2016; 15: 857-65. [PubMed: 27149842]

31. Overman MJ, McDermott R, Leach $\mathrm{JL}$, Lonardi S, Lenz HJ, Morse MA, Desai J, Hill A, Axelson M, Moss RA, 
Goldberg MV. Nivolumab in patients with metastatic DNA mismatch repair-deficient or microsatellite instability-high colorectal cancer (CheckMate 142): an open-label, multicentre, phase 2 study. The Lancet Oncology. 2017 Sep 1;18(9):1182-91 